\title{
Inhibition of Wnt signaling induces cell apoptosis and suppresses cell proliferation in cholangiocarcinoma cells
}

\author{
KUN-SONG ZHANG* , QI ZHOU*, YA-FENG WANG and LI-JIAN LIANG \\ Department of Hepatobiliary Surgery, The First Affiliated Hospital of Sun Yat-Sen University, \\ Guangzhou, Guangdong 510080, P.R. China
}

Received March 10, 2013; Accepted May 30, 2013

DOI: $10.3892 /$ or.2013.2560

\begin{abstract}
The aim of the present study was to explore possible gene therapy for hilar cholangiocarcinoma by detecting the activation of the Wnt signaling pathway in 4 cholangiocarcinoma cell lines and inhibiting its expression by RNA interference (RNAi) targeting key factors of this pathway. The expression levels of the Wnt pathway-related factors, Wnt2, Wnt $3, \beta$-catenin and transcription factor 4 , and its target genes, c-myc and cyclin D1, in 4 cholangiocarcinoma cell lines were detected by RT-PCR, western blotting and immunofluorescence microscopy. After transfection of siRNAs targeting Wnt 2 and $\beta$-catenin into FRH0201 cells, the expression of the Wnt pathway-related factors and its target genes was again detected, and the cell cycle distribution, apoptosis and proliferation were analyzed by flow cytometry and MTT assay. Activation of the Wnt pathway and the expression of its target genes were detected in all 4 cell lines at various levels. After siRNA transfection, the expression of the target genes in the FRH0201 cells was significantly downregulated. In addition, the Wnt pathway was blocked, cell apoptosis was enhanced and cell proliferation was suppressed. In conclusion, the Wnt signaling pathway is activated in cholangiocarcinoma cells. RNAi technology targeting Wnt 2 and $\beta$-catenin may be a possible gene therapy for hilar cholangiocarcinoma.
\end{abstract}

\section{Introduction}

Hilar cholangiocarcinoma, a malignant liver tumor that accounts for most cases of extrahepatic cholangiocarcinoma, is

Correspondence to: Dr Qi Zhou or Dr Li-Jian Liang, Department of Hepatobiliary Surgery, The First Affiliated Hospital of Sun Yat-Sen University, No. 58 Zhongshan 2nd Road, Guangzhou, Guangdong 510080, P.R. China

E-mail: zhouqi@mail.sysu.edu.cn

E-mail: lianglijian2001@163.com

*Contributed equally

Key words: hilar cholangiocacinoma, Wnt signaling pathway, RNA interference, FRH0212, HCCC-9810, SSP-25, RBE characterized by an occult course and specific location, which cause difficulties in its diagnosis and treatment. Previous prognostic studies have revealed that pathologic stage has no relationship with its prognosis (1). Therefore, a preoperative evaluation system which has a high correlation to surgical resection rates and prognoses is needed. In addition, the functions and mechanisms of this system in the genesis and progression of hilar cholangiocarcinoma should be elucidated to better distinguish this disease from intrahepatic types of tumors.

The Wnt signaling pathway regulates cell proliferation, differentiation, apoptosis and other biological processes. The activation of the Wnt pathway is closely related to tumorigenesis and progression of various types of tumors $(2,3)$. Its transient activation plays important roles in liver development $(4,5)$, liver cell regeneration (6), liver metabolism (7), oxygen stress (8) and other processes, thereby stimulating the progression of various chronic liver diseases, such as hepatitis B virus (HBV) infection (9) and hepatic fibrosis (10). In hepatocellular carcinoma (HCC), multiple factors in the Wnt pathway, such as Wnt, $\beta$-catenin, APC, Axin and sFRP1, are overexpressed in tumor cells $(11,12)$; more than 60 target genes of the Wnt pathway are activated by $\beta$-catenin/ TCF heterodimer, among which c-myc, c-jun, cyclin D1 and vascular endothelial growth factor (VEGF) are most commonly activated $(13,14)$. These aberrantly activated oncogenes, such as c-myc and cyclin D1, induce uncontrollable proliferation in liver cells and lead to the genesis of HCC. The aberrant activation of the Wnt pathway has been proven to closely relate with a subtype of cholangiocarcinoma (15). $\beta$-catenin gene mutations were detected in a few patients with cholangiocarcinoma, suggesting that tyrosine phosphorylation-dependent $\beta$-catenin activation or Wnt/ Frizzled dysfunction may contribute to the genesis of cholangiocarcinoma (16). Elucidating the functions and mechanisms of the Wnt pathway in cholangiocarcinoma, particularly hilar cholangiocarcinoma, will benefit the diagnosis and treatment of this disease.

In the present study, we detected the expression of the Wnt pathway-related factors, Wnt 2 , Wnt $3, \beta$-catenin and transcription factor 4 (TCF4), and its target genes, c-myc and cyclin D1, in 4 cholangiocarcinoma cell lines and blocked the Wnt pathway by RNA interference (RNAi) in order to explore potential gene therapy for hilar cholangiocarcinoma. 
Table I. Sequences of the RT-PCR primers.

\begin{tabular}{|c|c|c|c|c|}
\hline Gene & Primer sequences & $\operatorname{Tm}\left({ }^{\circ} \mathrm{C}\right)$ & $\mathrm{GC}\left({ }^{\circ} \mathrm{C}\right)$ & Length (bp) \\
\hline Wnt2 & $\begin{array}{l}\text { 5'-AACGCTGACTGGACAACCG-3' } \\
\text { 5'-GGGGCTTCCGTTGAGATAAA-3' }\end{array}$ & $\begin{array}{l}58.9 \\
59.3\end{array}$ & $\begin{array}{l}57.9 \\
50\end{array}$ & 158 \\
\hline Wnt3 & $\begin{array}{l}\text { 5'-CTGTGACTCGCATCATAAGGG-3' } \\
\text { 5'-GCCTCGTTGTTGTGCTTGTT-3' }\end{array}$ & $\begin{array}{l}58.1 \\
58.5\end{array}$ & $\begin{array}{l}52.4 \\
50\end{array}$ & 159 \\
\hline TCF4 & $\begin{array}{l}\text { 5'-CCCAGACTACTCCGTTCCT-3' } \\
\text { 5'-GGAAGCCGAAGATACAGG-3' }\end{array}$ & $\begin{array}{l}53.7 \\
52.5\end{array}$ & $\begin{array}{l}57.9 \\
55.6\end{array}$ & 143 \\
\hline$\beta$-catenin & $\begin{array}{l}\text { 5'-CAAGTGGGTGGTATAGAGG-3' } \\
\text { 5'-CTGGGTATCCTGATGTGC-3' }\end{array}$ & $\begin{array}{l}49.7 \\
50.5\end{array}$ & $\begin{array}{l}52.6 \\
55.6\end{array}$ & 327 \\
\hline c-myc & $\begin{array}{l}\text { 5'-GGGCTTTATCTAACTCGCTGTA-3' } \\
\text { 5'-GGGCAAAGTTTCGTGGAT-3' }\end{array}$ & $\begin{array}{l}56.5 \\
55.3\end{array}$ & $\begin{array}{l}45.5 \\
50\end{array}$ & 217 \\
\hline Cyclin D1 & $\begin{array}{l}\text { 5'-GCGAGGAACAGAAGTGCG-3' } \\
\text { 5'-GGATGGAGTTGTCGGTGTAGAT-3' }\end{array}$ & $\begin{array}{l}57 \\
58.1\end{array}$ & $\begin{array}{l}61.1 \\
50\end{array}$ & 195 \\
\hline GAPDH & $\begin{array}{l}\text { 5'-AACGTGTCAGTGGTGGACCT-3' } \\
\text { 5'-AGGGGAGATTCAGTGTGGTG-3' }\end{array}$ & $\begin{array}{l}60.48 \\
59.96\end{array}$ & $\begin{array}{l}55 \\
55\end{array}$ & 400 \\
\hline
\end{tabular}

RT-PCR, reverse transcription-polymerase chain reaction; TCF4, transcription factor 4. Tm, temperature.

\section{Materials and methods}

Cell lines and main reagents. Human hilar cholangiocarcinoma cell line FRH0201 was kindly gifted by Professor Xiaopeng $\mathrm{Wu}$ at the Department of General Surgery, Qilu Hospital, China, Shandong University. Human intrahepatic cholangiocarcinoma cell lines HCCC-9810, SSP-25 and RBE were purchased from Shanghai Cell Bank, Chinese Academy of Sciences.

RPMI-1640 culture medium containing fetal bovine serum (FBS), $0.25 \%$ trypsin, $1 \times 10^{5} \mathrm{U} / \mathrm{ml}$ penicillin and $10 \mathrm{mg} / \mathrm{ml}$ streptomycin were purchased from Gibco-BRL. MTT and DMSO solutions were produced by Sigma-Aldrich. TRizol, Lipofectamine $^{\mathrm{TM}}$ 2000, SuperScript ${ }^{\mathrm{TM}}$ II RNase $\mathrm{H}^{-}$reverse transcriptase, dATP, dGTP, dCTP and dTTP were produced by Invitrogen. The primary rabbit anti-human antibody was purchased from Santa Cruz Biotechnology, Inc. ECL detection solution, HRP-labeled secondary marker antibody, IgG Fc HRP-labeled goat anti-rabbit secondary antibody. The total protein extraction and BCA protein detection kits were purchased from Nanjing Keygen Biotech Co. (Nanjing, China).

Cell culture. Cells were cultured in RPMI-1640 medium containing either 10\% FBS (for FRH0201, HCCC-9810 and SSP-25 cells) or $20 \% \mathrm{FBS}$ (for RBE cells) at $37^{\circ} \mathrm{C}$ in $5 \% \mathrm{CO}_{2}$. After trypsin digestion and passage, cells were centrifuged at $1,000 \mathrm{x} \mathrm{g}$ for $5 \mathrm{~min}$, placed in a refrigerator at $4^{\circ} \mathrm{C}$ for $30 \mathrm{~min}$, and at $-20^{\circ} \mathrm{C}$ overnight, rethawed in water at $37^{\circ} \mathrm{C}$, again centrifuged at $1,000 \mathrm{x} \mathrm{g}$ for $5 \mathrm{~min}$, and cultured at $37^{\circ} \mathrm{C}$ in $5 \% \mathrm{CO}_{2}$.

Reverse transcription-polymerase chain reaction (RT-PCR). The mRNA expression levels of the Wnt pathway-related factors, Wnt2, Wnt3, $\beta$-catenin and TCF4, and its target genes, c-myc and cyclin D1, in FRH0201, HCCC-9810, SSP-25 and RBE cells were detected by RT-PCR. Total RNA was extracted from cells at a logarithmic growth phase with TRizol reagent according to the manufacturer's instructions and electrophoresed on agarose gel. The $20 \mu \mathrm{l}$ of RT solution was composed of $4.0 \mu \mathrm{l}$ of 5X RNA PCR buffer, $1.0 \mu \mathrm{l}$ of oligo dT-adaptor primer, $2.0 \mu \mathrm{l}$ of $10 \mathrm{mM}$ dNTP mixture, $0.625 \mu \mathrm{l}$ of RNase inhibitor, $1.0 \mu \mathrm{l}$ of $\mathrm{MV}$ reverse transcriptase, $9.375 \mu \mathrm{l}$ of RNase-free DEPC $\mathrm{H}_{2} \mathrm{O}$ and $2.0 \mu \mathrm{l}$ of sample RNA. The RT conditions were: $42^{\circ} \mathrm{C}$ for $30 \mathrm{~min}, 99^{\circ} \mathrm{C}$ for $5 \mathrm{~min}$, and $5^{\circ} \mathrm{C}$ for $5 \mathrm{~min}$.

The sequences of the genes were obtained from GenBank (http://www.ncbi.nlm.nih.gov/Genbank/). Primers were designed with Primer Expression 2.0 software (Table I) and synthesized by Invitrogen. GAPDH was used as internal reference. The $20 \mu \mathrm{l}$ of PCR solution was composed of $2.0 \mu \mathrm{l}$ of 10X buffer, $0.2 \mu \mathrm{l}$ of Blend Taq ${ }^{\circledR}, 3.0 \mu \mathrm{l}$ of $2 \mathrm{mM}$ dNTP, $1.0 \mu \mathrm{l}$ of template, $1.0 \mu \mathrm{l}$ of the upstream primer, $1.0 \mu \mathrm{l}$ of the downstream primer, and $11.8 \mu \mathrm{l}$ of $\mathrm{ddH}_{2} \mathrm{O}$. The PCR conditions were denaturation at $95^{\circ} \mathrm{C}$ for $5 \mathrm{~min}, 28$ cycles of annealing at $94^{\circ} \mathrm{C}$ for $30 \mathrm{sec}, 59^{\circ} \mathrm{C}$ for $30 \mathrm{sec}, 72^{\circ} \mathrm{C}$ for $1 \mathrm{~min}$, and $72^{\circ} \mathrm{C}$ for $10 \mathrm{~min}$, with elongation at $4^{\circ} \mathrm{C}$ for $1 \mathrm{~h}$. Finally, $1.0 \mu \mathrm{l}$ of PCR products were electrophoresed on $1.5 \%$ agarose gel at $100 \mathrm{~V}$ for 20 to $25 \mathrm{~min}$ and assessed with the gel imaging analysis system. The grey scale value of each well was determined with an image analyser. The relative mRNA level of target genes was calculated as the grey scale value of the target gene/grey scale value of GAPDH.

Western blot analysis. The protein expression levels of Wnt2, Wnt3, $\beta$-catenin, TCF4, c-myc and cyclin D1 in FRH0201, HCCC-9810, SSP-25 and RBE cells were detected by western blotting. Total protein was extracted from the cells with the KGP250 protein extraction kit (50 ml of lysis buffer, $250 \mu \mathrm{l}$ of phosphatase inhibitor, $50 \mu \mathrm{l}$ of protease inhibitor, $500 \mu \mathrm{l}$ of PMSF) and detected with the KGPBCA protein detection kit $(5 \mathrm{ml}$ of $0.5 \mu \mathrm{g} / \mu \mathrm{l}$ standard protein solution, $50 \mathrm{ml}$ of 
Table II. siRNA sequences.

\begin{tabular}{lclll}
\hline Gene & Target gene sequences & siRNA sequences & Molecular weight \\
\hline Wnt2 & 5'-GGATGCAAAGGAAAGGAAA-3' & 5'-GGAUGCAAAGGAAAGGAAA-dTdT-3' & 13,008.76 \\
& & 3'-dTdT-CCUACGUUUCCUUUCCUUU-5' & \\
3-catenin & 5'-GCCACAAGATTACAAGAAA-3' & 5'-GCCACAAGAUUACAAGAAA-dTdT-3' & 13,193.75 \\
& & 3'-dTdT-CGGUGUUCUAAUGUUCUUU-5' \\
\hline
\end{tabular}
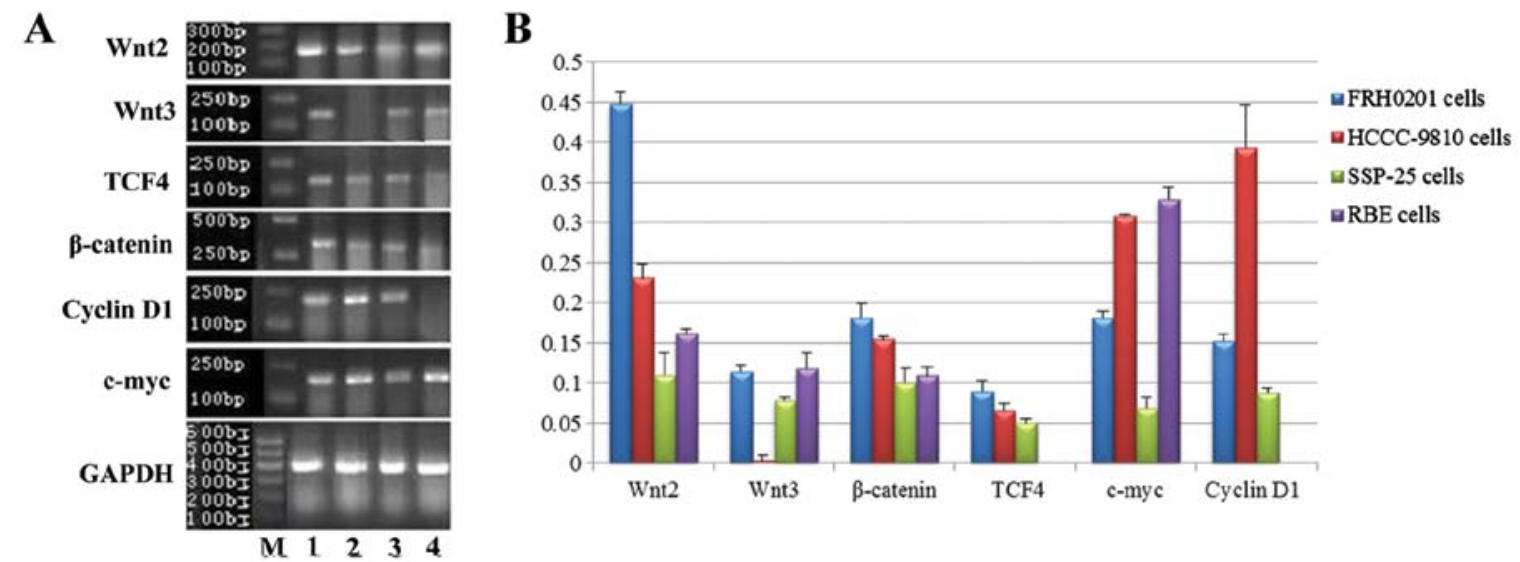

Figure 1. mRNA expression of Wnt2, Wnt3, $\beta$-catenin, TCF4, c-myc and cyclin D1 in FRH0201, HCCC-9810, SSP-25 and RBE cells as detected by RT-PCR. (A) Lane M, marker; lane 1, FRH0201 cells; lane 2, HCCC-9810 cells; lane 3, SSP-25 cells; lane 4, RBE cells. GAPDH was used as an internal reference. (B) Relative mRNA levels of Wnt2, Wnt3, $\beta$-catenin, TCF4, c-myc and cyclin D1 as compared with that of GAPDH.

BCA solution A, $1 \mathrm{ml}$ of BCA solution $\mathrm{B}$ ) according to the manufacturers' instructions. After SDS-PAGE electrophoresis, the protein was transferred on PVDF, blocked with TTBS (20 mM Tris- $\mathrm{HCl}, \mathrm{pH} 7.4,150 \mathrm{mM} \mathrm{NaCl}, 0.25 \%$ Tween-20, $5 \%$ fat-free milk powder) and washed with PBS for $10 \mathrm{~min}$. After adding the primary antibody (at 1:500 dilution), the protein was cultured at room temperature for $1 \mathrm{~h}$, washed with PBS for $10 \mathrm{~min}$, and the secondary antibody was added (at 1:1,000 dilution). Culturing was carried out for $1 \mathrm{~h}$ and then washing with PBS for $10 \mathrm{~min}$. After adding the ECL solution, the protein was cultured in the dark for $5 \mathrm{~min}$. The film was scanned and assessed with the gel imaging analysis system. The grey scale value of each well was measured with an image analyser. The relative protein level of the target proteins was calculated as the grey scale value of the target protein/grey scale value of GAPDH.

Immunofluorescence assay. The expression of Wnt 2 and $\beta$-catenin in FRH0201, HCCC-9810, SSP-25 and RBE cells was detected by immunofluorescence microscopy. Cells were seeded into 6 -well plates at a density of $1 \times 10^{6}$ cells/well, with 3 wells for each group, then fixed in acetone at room temperature for $20 \mathrm{~min}$, washed with PBS for 3 times, 5 min each time, punched with Triton- 100 at $37^{\circ} \mathrm{C}$ for $20 \mathrm{~min}$, washed with PBS, and blocked with non-immune animal serum at $37^{\circ} \mathrm{C}$ for $40 \mathrm{~min}$. After removing the serum, cells were added to the primary Wnt 2 or $\beta$-catenin antibody (at 1:100 dilution) and cultured at $4^{\circ} \mathrm{C}$ overnight. The next day, cells were washed with PBS, added together with FITC-labeled goat anti-rabbit secondary antibody and cultured in the dark at $37^{\circ} \mathrm{C}$ for $30 \mathrm{~min}$. After washing with PBS, cell nuclei were counterstained with Hoechst at $37^{\circ} \mathrm{C}$ for $20 \mathrm{~min}$, washed with PBS and blocked with $50 \%$ glycerin, then observed under a fluorescence microscope.

siRNA transfection. Wnt2-siRNA, $\beta$-catenin-siRNA and nonsense-siRNA were synthesized by RiboBio Co. (Guangzhou, China) (Table II). FRH0201 cells were digested and prepared into a single-cell suspension, seeded into 6-well plates at a density of $1 \times 10^{6}$ cells/well, with 3 wells for each group and cultured for 12 to $24 \mathrm{~h}$. Cells were washed with serum-free RPMI-1640 twice, then cultured with serum-free antibiotic-free RPMI-1640 (1.5 ml/well). Cells were transfected with siRNA (50 nM/well) for $4 \mathrm{~h}$ using Lipofectamine $\mathrm{e}^{\mathrm{TM}} 2000$ as a vector and then cultured with RPMI-1640 containing $10 \%$ FBS. At $6 \mathrm{~h}$ after transfection, cells were washed with PBS twice and observed under a fluorescence microscope. Fluorescence-labeled siRNA (FAM-siRNA) was used to assess transfection efficiency. Nonsense-siRNA-transfected cells were used as the negative control; untransfected cells were used as the blank control. At 48 to $72 \mathrm{~h}$ after transfection, the expression of $\mathrm{Wnt} 2, \mathrm{Wnt} 3, \mathrm{TCF} 4, \beta$-catenin, c-myc and cyclin D1 was detected by RT-PCR and western blotting; the expression of Wnt 2 and $\beta$-catenin was detected by immunofluorescence microscopy.

Flow cytometry. At 48 to $72 \mathrm{~h}$ after siRNA transfection, cells were cultured with $200 \mu \mathrm{l}$ of RNase A $(1 \mathrm{mg} / \mathrm{ml})$ at $37^{\circ} \mathrm{C}$ for $30 \mathrm{~min}$ and stained with propidium iodide (PI) at $4^{\circ} \mathrm{C}$ in the dark for $30 \mathrm{~min}$. Cell cycle distribution was assessed 
A

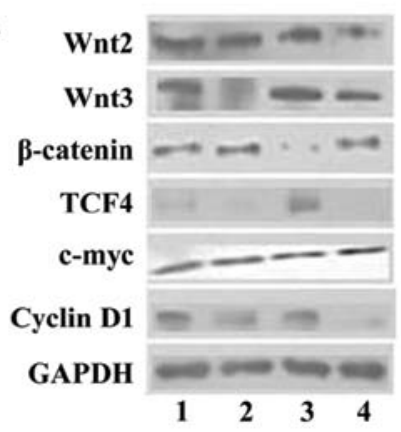

B

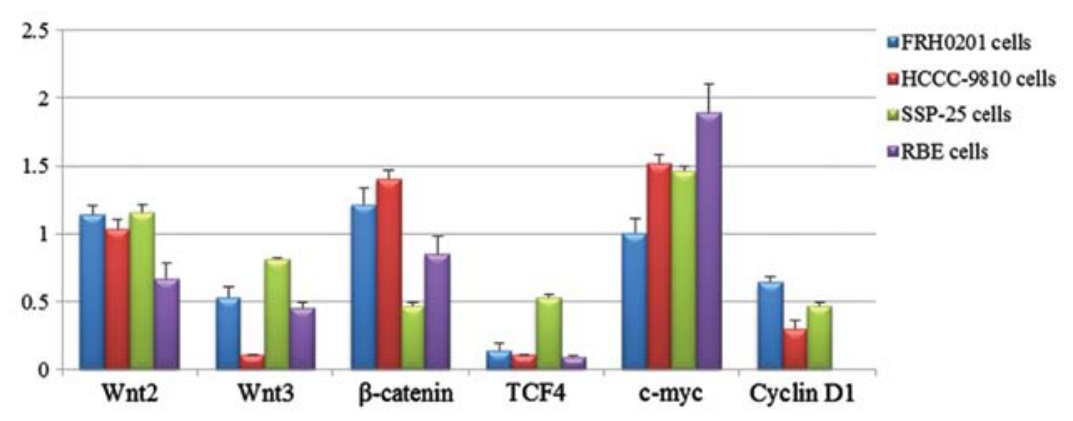

Figure 2. Protein expression of Wnt2, Wnt3, $\beta$-catenin, TCF4, c-myc and cyclin D1 in FRH0201, HCCC-9810, SSP-25 and RBE cells as detected by western blotting. (A) Lane 1, FRH0201 cells; lane 2, HCCC-9810 cells; lane 3, SSP-25 cells; lane 4, RBE cells. GAPDH was used as an internal reference. (B) Relative protein levels of Wnt2, Wnt3, $\beta$-catenin, TCF4, c-myc and cyclin D1 as compared with that of GAPDH.
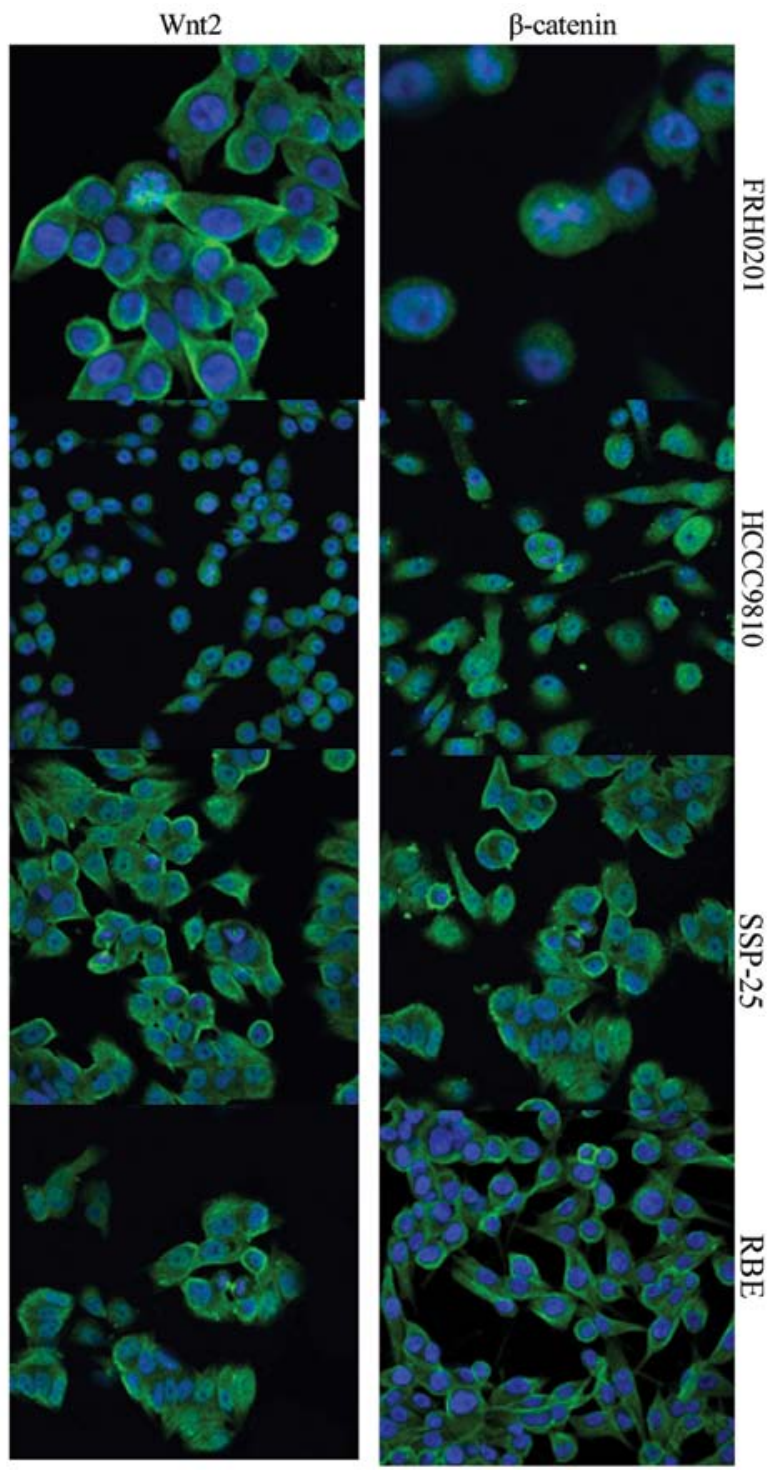

Figure 3. Expression of Wnt 2 and $\beta$-catenin in FRH0201, HCCC-9810, SSP-25 and RBE cells as detected by immunofluorescence microscopy. Green fluorescence indicates target proteins; blue fluorescence indicates cell nuclei.

by FACScan flow cytometry with an excitation wavelength of $488 \mathrm{~nm}$. After Annexin V-FITC/PI double staining, cell apoptosis was also assessed by FACScan flow cytometry. Cells without Annexin V-FITC or PI staining were used as the negative control.

MTT assay. Before siRNA transfection and at 24, 48, $72 \mathrm{~h}$ after transfection, cells at a density of $5 \times 10^{5}$ cells $/ \mathrm{ml}$ were seeded into a 96 -well plate $\left(1 \times 10^{4}\right.$ cells/well $)$, with 8 wells for each group, and $5 \mathrm{mg} / \mathrm{ml}$ MTT (20 $\mu \mathrm{l} /$ well) was added and cultured at $37^{\circ} \mathrm{C}$ for $4 \mathrm{~h}$. After discarding the supernatant, cells were mixed with DMSO (200 $\mu \mathrm{l} / \mathrm{well})$ for $10 \mathrm{~min}$. The absorbance of each well at $570 \mathrm{~nm}\left(\mathrm{~A}_{570}\right)$ was measured by an ultraviolet spectrophotometer, and the cell proliferation rate was calculated as $\left(\mathrm{A}_{570}\right.$ of siRNA-transfected cells - $\mathrm{A}_{570}$ of blank control $) /\left(\mathrm{A}_{570}\right.$ of negative control - $\mathrm{A}_{570}$ of blank control) x $100 \%$.

Statistical analyses. All experiments were repeated three times. The data are presented as mean \pm standard deviation (SD). SPSS13.0 software was used for statistical analyses. Homogeneity of variance was assessed by the Levene's test. Intergroup comparison was performed with the ANOVA test when the variance was homogeneous or with the Wilcoxon test when the variance was heterogeneous. A value of $\mathrm{P}<0.05$ was considered to indicate a statistically significant difference.

\section{Results}

mRNA expression of the Wnt pathway-related factors and target genes as detected by RT-PCR. The integrity and purity of total RNA extracted from the cells were confirmed by electrophoresis. The mRNA levels of Wnt2, Wnt3, $\beta$-catenin, TCF4, c-myc and cyclin D1 varied in the 4 cell lines (Fig. 1). The mRNA expression levels of Wnt $2, \mathrm{Wnt} 3, \beta$-catenin and c-myc were detectable in all 4 cell lines, whereas TCF4 and cyclin D1 mRNA were undetectable in RBE cells.

The mRNA levels (from high to low) in the cells were FRH0201 > HCCC-9810 > RBE $>$ SSP-25 for Wnt2 ( F=199.499, $\mathrm{P}<0.001) ; \mathrm{RBE} \approx \mathrm{FRH} 0201>\mathrm{SSP}-25>\mathrm{HCCC}-9810$ for Wnt3 ( F=68.927, P<0.001); FRH0201 $\approx$ HCCC$9810>$ SSP-25 > RBE for $\beta$-catenin $(\mathrm{F}=21.924, \mathrm{P}<0.001)$; $\mathrm{RBE} \approx \mathrm{HCCC}-9810>\mathrm{FRH} 0201>\mathrm{SSP}-25$ for $\mathrm{c}-\mathrm{myc}$ $(\mathrm{F}=179.284, \mathrm{P}<0.001) ; \mathrm{FRH} 0201 \approx \mathrm{HCCC}-9810 \approx \mathrm{SSP}-25$ for TCF4 $(\mathrm{P}>0.05)$; and HCCC-9810 $\approx$ FRH0201 $\approx$ SSP-25 for cyclin D1 ( $>0.05)$. 

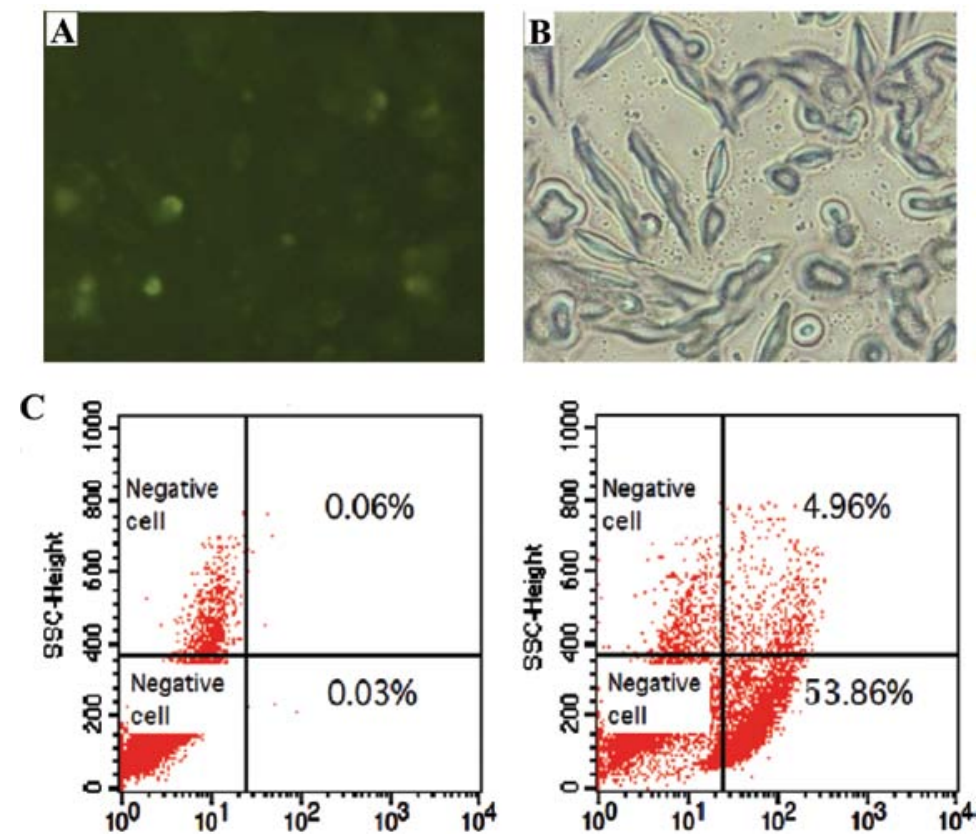

Figure 4. siRNA transfection efficiency as detected by both fluorescence microscopy (x400) and flow cytometry. (A) Under a fluorescence microscope, green fluorescence indicates siRNA-transfected cells, with a positive rate of $>50 \%$. (B) The integrity of FRH09201 cells in the same field can be observed under a phase contrast microscope. (C) The detection rate of positive fluorescence, indicating the siRNA transfection efficiency, is $53.86 \%$.

A

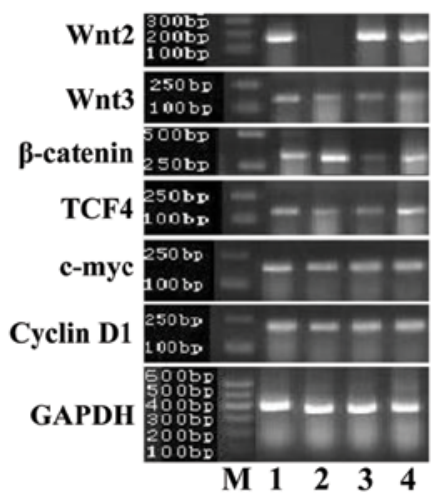

B 0.

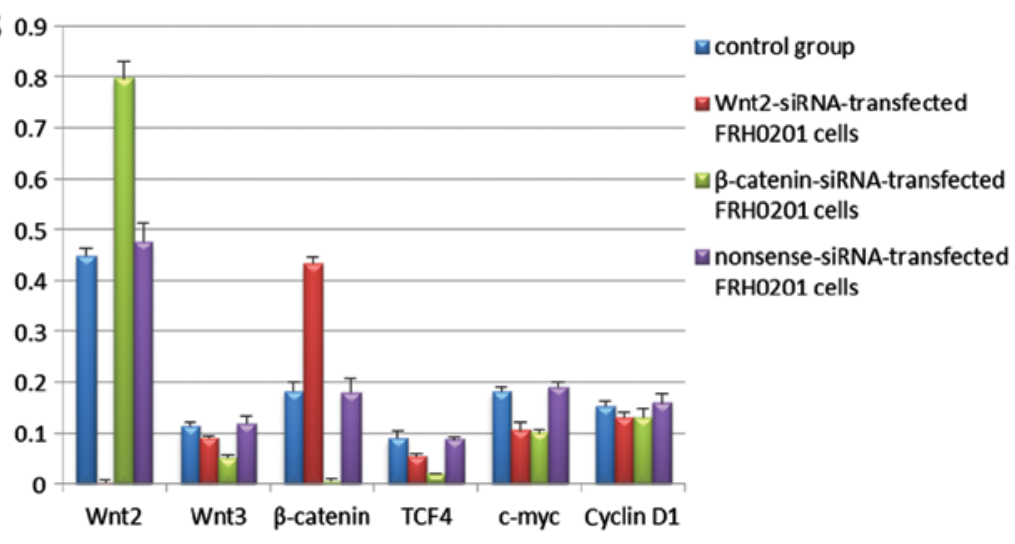

Figure 5. mRNA expression of Wnt2, Wnt3, $\beta$-catenin, TCF4, c-myc and cyclin D1 in FRH0201 cells after siRNA transfection. (A) Lane M, marker; lane 1, blank control; lane 2, Wnt2-siRNA-transfected FRH0201 cells; lane 3, $\beta$-catenin-siRNA-transfected FRH0201 cells; lane 4, nonsense-siRNA-transfected FRH0201 cells. GAPDH was used as an internal reference. (B) Relative mRNA levels of Wnt2, Wnt3, $\beta$-catenin, TCF4, c-myc and cyclin D1 as compared with that of GAPDH.

Protein expression of the Wnt pathway-related factors and target genes detected by western blotting. The protein expression of Wnt2, Wnt3, $\beta$-catenin, TCF4, c-myc and cyclin D1 was detected at various levels (Fig. 2). The protein expression levels of Wnt2, Wnt $3, \beta$-catenin, TCF4 and c-myc were detectable in all 4 cell lines, whereas cyclin D1 protein expression was undetectable in the RBE cells.

The protein levels (from high to low) in the cells were SSP-25 $\approx$ FRH0201 $\approx$ HCCC-9810 $>$ RBE for Wnt $2(\mathrm{~F}=24.753$, $\mathrm{P}<0.001)$; SSP- $25 \approx$ FRH0201 $\approx$ RBE $\approx$ HCCC-9810 for Wnt 3 $(\mathrm{P}>0.05)$; HCCC-9810 > FRH0201 > RBE $>$ SSP-25 for $\beta$-catenin $(\mathrm{F}=58.665, \mathrm{P}<0.001)$; SSP- $25 \approx \mathrm{FRH} 0201 \approx \mathrm{HCCC}-$ $9810 \approx$ RBE for TCF4 $(\mathrm{P}>0.05)$; RBE $>$ HCCC $-9810 \approx$ SSP- $25>$ FRH0201 for c-myc $(\mathrm{F}=25.208, \mathrm{P}<0.001)$; and FRH0201 $\approx$ SSP- $25 \approx$ HCCC-9810 for cyclin D1 ( $>>0.05)$.
Expression of Wnt 2 and $\beta$-catenin as detected by immunofluorescence microscopy. Immunofluorescent staining showed that Wnt2 was expressed both in the cytoplasm and on the cell membrane, whereas $\beta$-catenin was expressed on the cell membrane and in cytoplasm and nuclei (Fig. 3). Consistent with the results of the western blot analysis, both Wnt2 and $\beta$-catenin were highly expressed in the 4 cell lines. The expression of Wnt2 was similar in the FRH0201, HCCC-9810 and SSP-25 cells, and was relatively weaker in the RBE cells. The expression of $\beta$-catenin was stronger in the FRH0201 and HCCC-9810 cells, but was weaker in the SSP-25 cells.

siRNA transfection efficiency. As detected by both fluorescence microscopy and flow cytometry, siRNA was transfected into the FRH0201 cells, with a transfection efficiency of 53.9\% (Fig. 4). 
$\mathbf{A}$

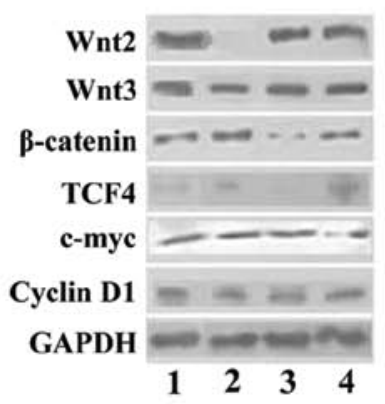

B

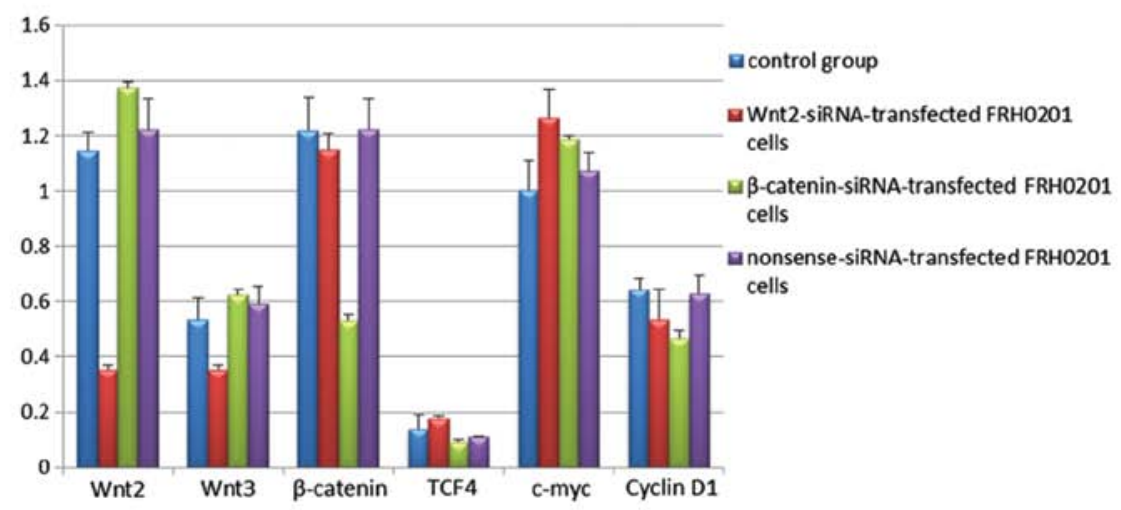

Figure 6. Protein expression of Wnt2, Wnt3, $\beta$-catenin, TCF4, c-myc and cyclin D1 in FRH0201 cells after siRNA transfection. (A) Lane 1, blank control; lane 2, Wnt2-siRNA-transfected FRH0201 cells; lane 3, $\beta$-catenin-siRNA-transfected FRH0201 cells; lane 4, nonsense-siRNA-transfected FRH0201 cells. GAPDH was used as an internal reference. (B) Relative protein levels of Wnt2, Wnt3, $\beta$-catenin, TCF4, c-myc and cyclin D1 as compared with that of GAPDH.

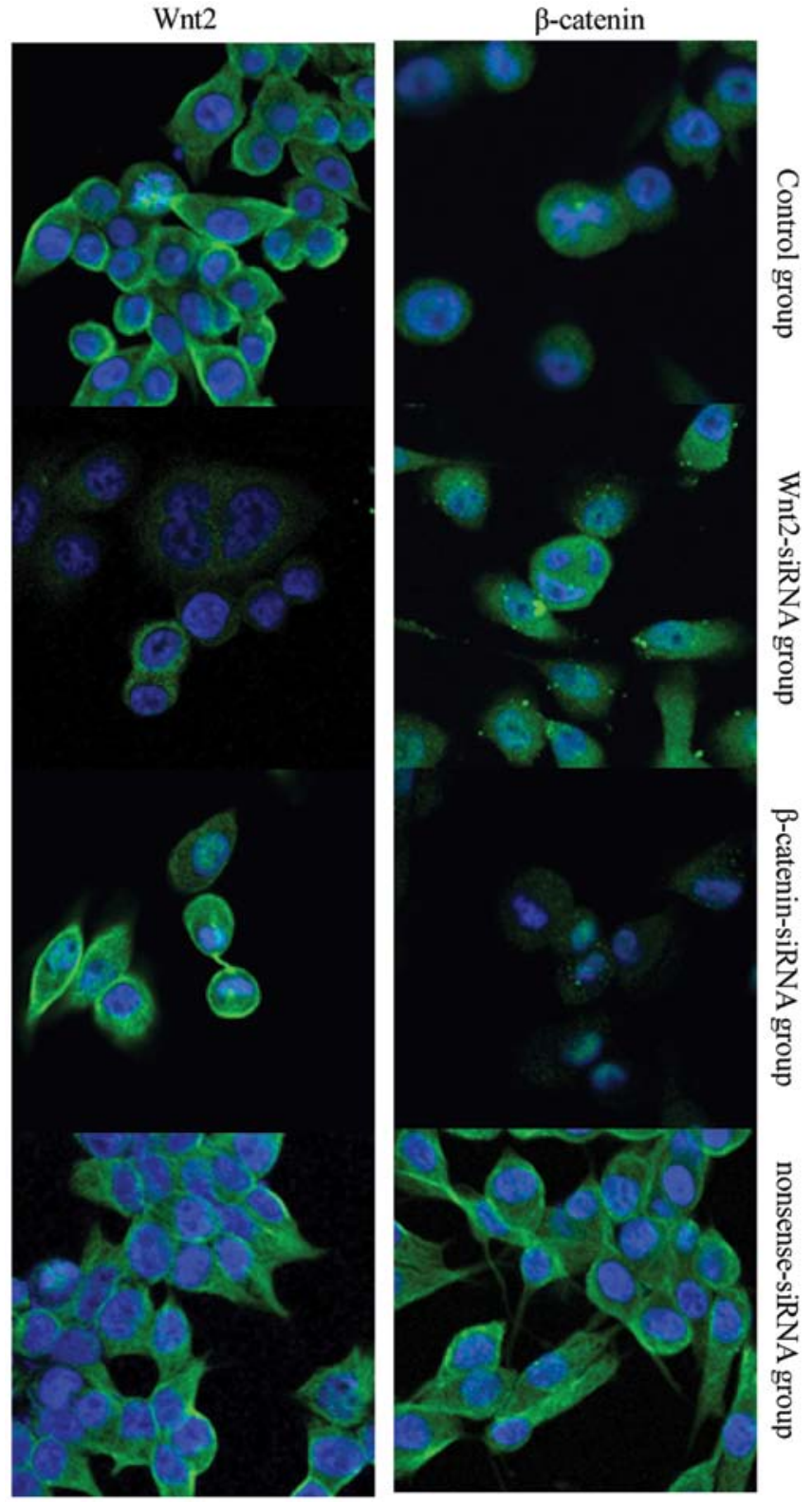

Figure 7. Expression of Wnt 2 and $\beta$-catenin in FRH0201 cells after siRNA transfection. Green fluorescence indicates the target protein; blue fluorescence indicates cell nuclei.
mRNA expression of the Wnt pathway-related factors and target genes after siRNA transfection. After siRNA transfection, the mRNA expression of the factors was obviously altered (Fig. 5). The expression of cyclin D1 was similar in the 4 groups. In the Wnt2-siRNA group, the mRNA levels of Wnt2, Wnt3, TCF4 and c-myc were downregulated, whereas that of $\beta$-catenin was upregulated. In the $\beta$-catenin-siRNA group, the mRNA levels of $\beta$-catenin, Wnt3, TCF4 and c-myc were downregulated, whereas that of Wnt 2 was upregulated. The mRNA levels of Wnt $3, \beta$-catenin and TCF4 were lower in the $\beta$-catenin-siRNA group than levels in the Wnt2-siRNA group, whereas that of Wnt2 was lower in the Wnt2-siRNA group than that in the $\beta$-catenin-siRNA group. No significant differences were observed between the nonsense-siRNA and blank control groups.

Protein expression of the Wnt pathway-related factors and target genes after siRNA transfection. After siRNA transfection, the protein expression of the factors was also obviously altered (Fig. 6). The expression of TCF4 and cyclin D1 was similar in the 4 groups. In the Wnt2-siRNA group, the protein levels of Wnt 2 and Wnt 3 were downregulated, whereas that of c-myc was upregulated. In the $\beta$-catenin-siRNA group, the protein level of $\beta$-catenin was downregulated, whereas that of c-myc was upregulated. The protein levels of Wnt2 and Wnt3 were lower in the Wnt2-siRNA group than levels in the $\beta$-catenin-siRNA group, whereas that of $\beta$-catenin was lower in the $\beta$-catenin-siRNA group than that in the Wnt2-siRNA group. No significant differences were observed between the nonsense-siRNA and blank control groups.

Protein expression of Wnt 2 and $\beta$-catenin after siRNA transfection. The results of fluorescence microscopy (Fig. 7) were consistent with the results of the western blot analysis. In the Wnt2-siRNA group, the cytoplasm and membrane staining was weaker for Wnt2, but the cytoplasmic staining for $\beta$-catenin was unchanged. In the $\beta$-catenin-siRNA group, the cytoplasm and membrane stained weaker for $\beta$-catenin, but the staining for Wnt2 was unchanged. No significant differences were observed between the nonsense-siRNA and blank control groups. 

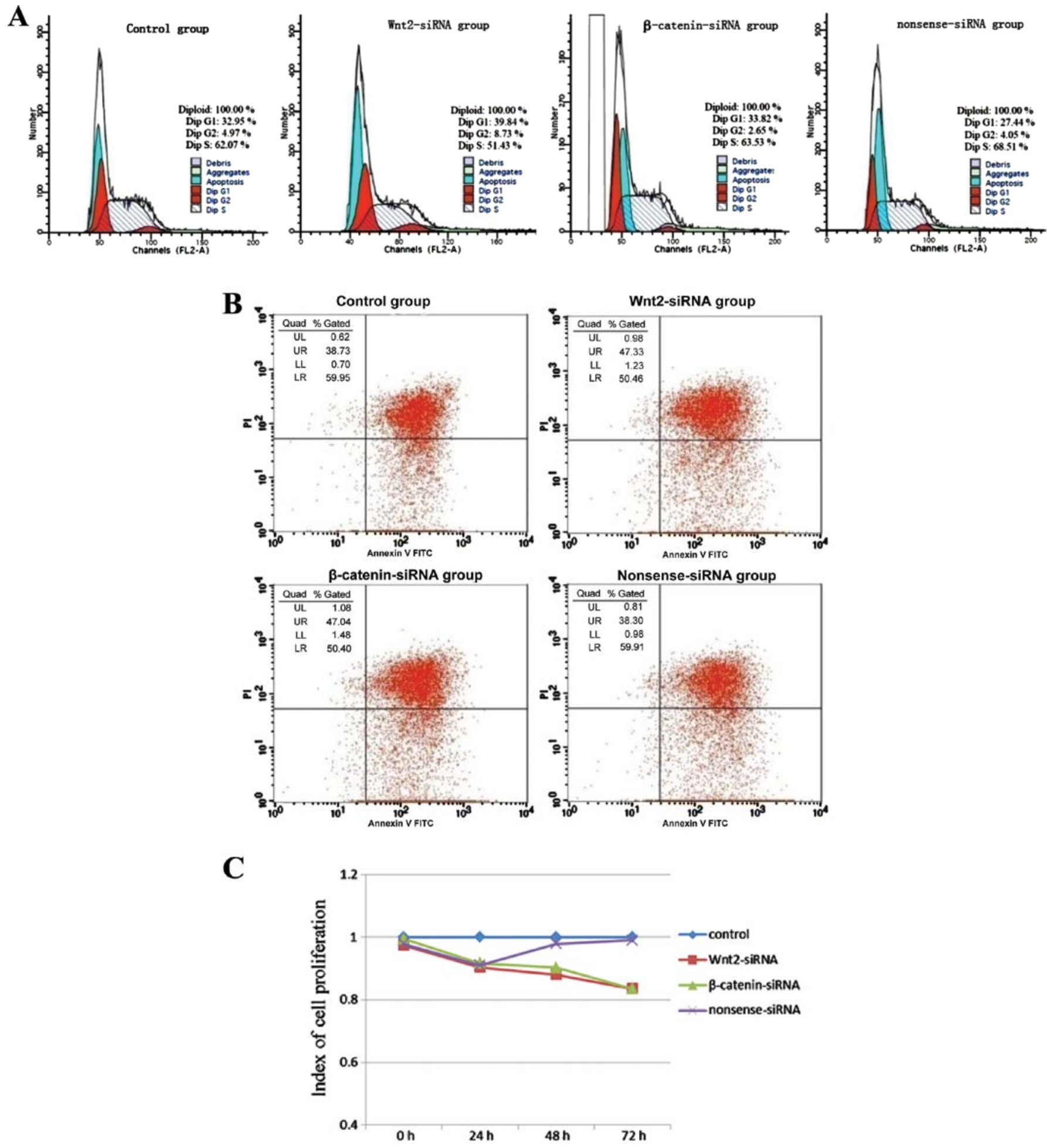

Figure 8. Cell cycle, apoptosis and proliferation of FRH0201 cells after siRNA transfection. (A) FRH0201 cells underwent G0/G1 phase arrest following Wnt2-siRNA transfection. (B) Annexin V/PI double staining revealed an increase in cell apoptosis after cells were transfected with either Wnt2-siRNA or $\beta$-catenin-siRNA. (C) Cell proliferation curves indicate a decrease in cell proliferation after cells were transfected with either Wnt2-siRNA or $\beta$-cateninsiRNA.

Cell cycle distribution, apoptosis, and proliferation of FRH0201 cells after siRNA transfection. Flow cytometry showed that the proportion of $\mathrm{S}$ phase cells was decreased after siRNA transfection; $G_{0} / G_{1}$ phase arrest was observed in the Wnt2-siRNA group (Fig. 8A). The difference in cell apoptosis rate was significant between the 4 groups $(45.1 \pm 2.9 \%$ for the blank control group; $50.1 \pm 2.8 \%$ for the Wnt2-siRNA group;
$50.5 \pm 3.1 \%$ for the $\beta$-catenin-siRNA group and $42.9 \pm 4.0 \%$ for the nonsense-siRNA group; $\mathrm{F}=6.589, \mathrm{P}=0.015$ ); the apoptosis rate was significantly higher in the Wnt2-siRNA and $\beta$-cateninsiRNA groups than in the blank control and nonsense-siRNA groups (all $\mathrm{P}<0.05$ ) (Fig. 8B). The difference in cell proliferation rate was also significant between the 4 groups $(\mathrm{F}=7.792$, $\mathrm{P}=0.001$ ); the proliferation rate was significantly lower in the 
Wnt2-siRNA and $\beta$-catenin-siRNA groups than in the blank control and nonsense-siRNA groups (all $\mathrm{P}<0.05$ ) (Fig. 8C).

\section{Discussion}

In the present study, we demonstrated that the Wnt pathway is activated in cholangiocarcinoma cells. Blocking the Wnt pathway by RNAi enhanced cell apoptosis and suppressed cell proliferation.

Currently, only a few extrahepatic cholangiocarcinoma cell lines have been established (17), and two of them were established in China [QBC939 (18) and FRH0201 (19)]. These cell lines, originating from either extrahepatic primary lesions or intrahepatic metastases, provide ideal experimental models for the study of hilar cholangiocarcinoma. In the present study, we selected the FRH0201 cell line originating from primary hilar cholangiocarcinoma lesions and 3 cell lines originating from intrahepatic cholangiocarcinoma lesions as controls. We found high expression of Wnt, $\beta$-catenin, TCF4 and target gene c-myc in all 4 cell lines, indicating activation of the Wnt pathway in both hilar and intrahepatic cholangiocarcinoma cell lines. The expression levels of the Wnt pathway-related factors varied in the 3 intrahepatic cholangiocarcinoma cell lines, but all were lower than those in the hilar cholangiocarcinoma FRH0201 cells, suggesting that the activation level of the Wnt pathway differs between hilar cholangiocarcinoma and intrahepatic cholangiocarcinoma and that the mechanisms of the Wnt pathway may be different in the two types of cholangiocarcinomas.

Uematsu et al (20) and Davies et al (21) found that RNAi targeting the Wnt pathway induced tumor cell apoptosis and inhibited cell proliferation in renal cancer and non-small cell lung cancer. Therefore, we hypothesized that blocking the Wnt pathway by RNAi may also be a potential gene therapy for cholangiocarcinoma. $\beta$-catenin, a key factor in the Wnt pathway, plays important roles in the development and progression of hepatoblastoma, HCC and cholangiocarcinoma. Sangkhathat et al (22) transfected $\beta$-catenin-siRNA into the $\beta$-catenin-mutant pediatric hepatoblastoma cell line $\mathrm{HuH}-6$ and the HCC cell line HepG2. After transfection, the expression of $\beta$-catenin, c-myc and cyclin D1 was downregulated, and cell proliferation and invasion were suppressed (22). Wnt2, a member of the Wnt family, is overexpressed in various digestive tract tumors and lung cancer. A recent study with HCC cell lines found that Wnt 3 and Frizzled7 also activated the Wnt pathway and played important roles in the genesis and progression of HCC (23). Mazieres et al (24) transfected Wnt2-siRNA into Wnt2-overexpressed malignant pleural mesothelioma cell lines and found similar results. In the present study, we found that the mRNA and protein levels of Wnt2 as well as the mRNA level of $\beta$-catenin were downregulated after Wnt2-siRNA transfection. Although the downregulation of $\beta$-catenin protein level was not obvious, immunofluorescence microscopy revealed decreased nuclear expression and increased cytoplasmic and membrane expression of $\beta$-catenin, suggesting that Wnt2-siRNA inhibits the nuclear accumulation of $\beta$-catenin, thus blocking the Wnt pathway. We also found that the mRNA and protein levels of $\beta$-catenin as well as the mRNA level of Wnt3 were downregulated after $\beta$-catenin-siRNA transfection, confirming that
Wnt3 was related to the cytoplasmic expression of $\beta$-catenin. The 'seesaw-like' relationship between Wnt 2 and $\beta$-catenin at the translation level is considered to be related with multiple factors that are involved in the activation or inhibition of the Wnt pathway. Cyclin D1 was proven to play an important role in hilar cholangiocarcinoma, but was not associated with the activation of the Wnt pathway (25). Upregulation of cyclin D1 protein level was noted after $\beta$-catenin-siRNA transfection, suggesting that $\beta$-catenin regulates the expression of cyclin D1 via other pathways. The detailed mechanisms need to be elucidated in our future research.

Our results showed that using RNAi to knock down Wnt2 or $\beta$-catenin and block the Wnt pathway obviously inhibited cell proliferation, enhanced cell apoptosis, and arrested the cell cycle at the $G_{0} / G_{1}$ phase. The regulation of cell apoptosis and proliferation by c-myc and cyclin D1 was closely related to alterations of many other genes (26). The mechanisms of the downregulation of c-myc mRNA level and cyclin D1 protein level after $\beta$-catenin-siRNA transfection warrant further study.

In conclusion, the Wnt pathway was activated in both the hilar cholangiocarcinoma cell line FRH0201 and the intrahepatic cholangiocarcinoma cell lines HCCC-9810, SSP-25 and RBE, but the expression levels of its key factors Wnt2, Wnt3, TCF 4 and $\beta$-catenin and its target genes c-myc and cyclin D1 varied in the 4 cell lines. RNAi targeting Wnt2 and $\beta$-catenin downregulated the expression of these two genes in FRH0201 cells, inhibited the activation of the Wnt pathway, downregulated the expression of c-myc, promoted cell apoptosis and inhibited cell proliferation, suggesting that Wnt2 and $\beta$-catenin could be key targets for the gene therapy of hilar cholangiocarcinoma.

\section{References}

1. Saxena A, Chua TC, Chu FC and Morris DL: Improved outcomes after aggressive surgical resection of hilar cholangiocarcinoma: a critical analysis of recurrence and survival. Am J Surg 202: 310-320, 2011.

2. Lu D, Zhao Y, Tawatao R, et al: Activation of the Wnt signaling pathway in chronic lymphocytic leukemia. Proc Natl Acad Sci USA 101: 3118-3123, 2004.

3. Ilyas M: Wnt signalling and the mechanistic basis of tumour development. J Pathol 205: 130-144, 2005.

4. Monga SP, Monga HK, Tan X, Mulé K, Pediaditakis P and Michalopoulos GK: Beta-catenin antisense studies in embryonic liver cultures: role in proliferation, apoptosis, and lineage specification. Gastroenterology 124: 202-216, 2003.

5. Micsenyi A, Tan X, Sneddon T, Luo JH, Michalopoulos GK and Monga SP: Beta-catenin is temporally regulated during normal liver development. Gastroenterology 126: 1134-1146, 2004.

6. Monga SP, Pediaditakis P, Mule K, Stolz DB and Michalopoulos GK: Changes in WNT/beta-catenin pathway during regulated growth in rat liver regeneration. Hepatology 33: 1098-1109, 2001.

7. Benhamouche S, Decaens T, Godard C, et al: Apc tumor suppressor gene is the 'zonation-keeper' of mouse liver. Dev Cell 10: 759-770, 2006

8. Funato Y, Michiue T, Asashima M and Miki H: The thioredoxin-related redox-regulating protein nucleoredoxin inhibits Wnt-beta-catenin signalling through dishevelled. Nat Cell Biol 8: 501-508, 2006.

9. Lian Z, Liu J, Li L, et al: Enhanced cell survival of Hep3B cells by the hepatitis B $x$ antigen effector, URG11, is associated with upregulation of beta-catenin. Hepatology 43: 415-424, 2006.

10. Higashi N, Kojima N, Miura M, Imai K, Sato M and Senoo H: Cell-cell junctions between mammalian (human and rat) hepatic stellate cells. Cell Tissue Res 317: 35-43, 2004. 
11. Guan CN, Chen XM, Lou HQ, Liao XH, Chen BY and Zhang PW: Clinical significance of axin and beta-catenin protein expression in primary hepatocellular carcinomas. Asian Pac J Cancer Prev 13: 677-681, 2012.

12. Kaur P, Mani S, Cros MP, et al: Epigenetic silencing of sFRP1 activates the canonical Wnt pathway and contributes to increased cell growth and proliferation in hepatocellular carcinoma. Tumour Biol 33: 325-336, 2012.

13. Loeppen S, Koehle C, Buchmann A and Schwarz M: A beta-catenin-dependent pathway regulates expression of cytochrome $\mathrm{P} 450$ isoforms in mouse liver tumors. Carcinogenesis 26 : 239-248, 2005

14. Tien LT, Ito M, Nakao M, et al: Expression of beta-catenin in hepatocellular carcinoma. World J Gastroenterol 11: 2398-2401, 2005.

15. Tokumoto N, Ikeda S, Ishizaki Y, et al: Immunohistochemical and mutational analyses of Wnt signaling components and target genes in intrahepatic cholangiocarcinomas. Int J Oncol 27 : 973-980, 2005.

16. Sugimachi K, Taguchi K, Aishima S, et al: Altered expression of beta-catenin without genetic mutation in intrahepatic cholangiocarcinoma. Mod Pathol 14: 900-905, 2001.

17. Ku JL, Yoon KA, Kim IJ, et al: Establishment and characterisation of six human biliary tract cancer cell lines. Br J Cancer 87 187-193, 2002

18. Takiyama I, Terashima M, Ikeda K, et al: Establishment and characterization of a new human extrahepatic bile duct carcinoma cell line (ICBD-1). Oncol Rep 5: 463-467, 1998.

19. Tang WH, Yuan ST, Wang BS, Lu LJ, Ding J and Yuan ZR: Establishment of a subcutaneous model of the human extrahepatic bile duct carcinoma in nude mice via transplantation of histologically intact tumor tissue. J Exp Clin Cancer Res 23: 661-667, 2004
20. Uematsu K, He B, You L, Xu Z, McCormick F and Jablons DM: Activation of the Wnt pathway in non small cell lung cancer: evidence of dishevelled overexpression. Oncogene 22: 7218-7221, 2003.

21. Davies JA, Ladomery M, Hohenstein P, et al: Development of an siRNA-based method for repressing specific genes in renal organ culture and its use to show that the Wt1 tumour suppressor is required for nephron differentiation. Hum Mol Genet 13: 235-246, 2004

22. Sangkhathat S, Kusafuka T, Miao J, et al: In vitro RNA interference against $\beta$-catenin inhibits the proliferation of pediatric hepatic tumors. Int J Oncol 28: 715-722, 2006.

23. Kim M, Lee HC, Tsedensodnom O, et al: Functional interaction between Wnt3 and Frizzled-7 leads to activation of the Wnt/betacatenin signaling pathway in hepatocellular carcinoma cells. J Hepatol 48: 780-791, 2008.

24. Mazieres J, You L, He B, et al: Wnt2 as a new therapeutic target in malignant pleural mesothelioma. Int J Cancer 117: 326-332, 2005.

25. Zhao P, Lu Y, Zhong M, Liu L and Li B: Inverse correlation of aberrant expression of fragile histidine triad (FHIT) protein with cyclin D1 protein and prognosis in Chinese patients with cholangiocarcinoma. Acta Oncol 47: 1557-1563, 2008

26. El-Kady A, Sun Y, Li YX and Liao DJ: Cyclin D1 inhibits whereas c-Myc enhances the cytotoxicity of cisplatin in mouse pancreatic cancer cells via regulation of several members of the NF- $\kappa$ B and Bcl-2 families. J Carcinog 10: 24, 2011. 